\title{
Foreword
}

\section{Frank Moulaert}

The main focus of Social Innovation and Urban Governance: Citizenship, Civil Society and Social Movements is the impact of socially innovative initiatives and citizen practices on (local) governance in Southern European cities before and after the 2008 financial crisis. I am convinced that the success and failure of governance experiences that it analyses and explains are of dramatic importance for the future of 'the good life for all' in Europe and the world. For almost 30 years now, social innovation (action) researchers have made the connection between socially innovative initiatives in citizens' organizations on the one hand, and the search 'to democratize democracy' on the other. Bottom-up organizations claiming equity and voice preceded the financial crisis of 2008 as well as the industrial restructuring that started after the oil crisis of the 1970s and that continues to the present day in several cities, often at an accelerated pace. For sure, with the growing number of crisis victims and as crisis conditions have infiltrated middle- and even upper middle-class cohorts, more people have become 'Indignants' and joined movements of resistance and action to rebuild communities in society. It may sound sad that so-called bourgeois citizens have had to watch their certainties (decent, well-paid jobs, caring social security systems, education as a warrant to prosperity, a voice heard through the political system, etc.) melt before their eyes before taking action and joining up with excluded citizens and migrants to build movements capable of returning equity and dignity to our so-called market democracy.

This book explains the micro-architecture of civil society organizations and social movements that have become political, particularly in cities of Southern Europe, providing a detailed empirical analysis for the cities of Barcelona, Zaragoza, Bilbao and Madrid. It documents how groups of concerned and crisis-struck citizens unite around economic and social issues: food shortages, job losses, the disappearance of social services due to severe cuts in the public budget, lack of income to pay for clothing, education, leisure, housing, etc.

Social Innovation and Urban Governance: Citizenship, Civil Society and Social Movements not only analyses change movements from the perspective of what is traditionally called a 'basic needs satisfaction', it takes this discussion further and investigates the socio-politically transformative potential of the movements in rebuilding solidarity in social relations and governance 
systems. Thus, in my opinion, the most significant value added of the book is the way it analyses the organizational build-up of the movements, their political and ideological roots and connections - or lack thereof - and the ways in which they have become, or have failed to become, political. It demonstrates how movements - since their inception - have experimented with (new) forms of collective decision making, democratic organization and management. It also shows their concern with their political impact: namely with how to translate their actions into political agendas advocating for sustaining and reinforcing local welfare systems, fairer distribution of economic resources, democratic public agencies, urban policy focused on affordable housing, accessible social services and public space and so on. Change movements in several Southern European cities have evolved into invigorated and influential governance actors and often into new political movements and parties. As a result, the ethics of solidarity and shared decision making are slowly re-entering public decision-making arenas sowing the seeds for dignity-based modes of governance. The book provides evidence of bottom-linked governance experiments in prominent Southern European cities, in which public servants, local politicians, movement leaders, concerned citizens and migrants become engaged in a shared, reflexive learning process. And although 'success is not guaranteed', the stories of these experiences should be shared and learned from. That is why this book is a must read for anyone caring about the future of (urban) solidarity and democracy. 